\title{
"In vitro" Evaluation of Some Properties in Spore Former Bacteria Isolated from Calves Faeces
}

\author{
Natalia Cecilia Maldonado ${ }^{1}$, Clara Silva de Ruiz ${ }^{2}$ \\ and María Elena Fátima Nader-Macías ${ }^{1^{\star}}$ \\ ${ }^{1}$ Centro de Referencia Para Lactobacilos (CERELA-CONICET), Chacabuco 145. 4000, San Miguel \\ de Tucumán, Argentina. \\ ${ }^{2}$ Facultad de Bioquímica, Química y Farmacia. UNT, Ayacucho 491. 4000, San Miguel de Tucumán, \\ Argentina.
}

\section{Authors' contributions}

This work was carried out in collaboration between all authors. Author NCM wrote the protocol, performed the experimental assays, and wrote the first draft of the manuscript. Author CSR performed some assays, author MEFNM designed the study, wrote the protocol and managed the analyses of the study and literature searches, authors NCM and MEFNM performed the statistical analysis and managed the analyses of the study and literature searches. All authors read and approved the final

manuscript.

Article Information

DOI: 10.9734/BMRJ/2016/21943

Editor(s):

(1) Giuseppe Blaiotta, Department of Food Science, Via Università, Italy.

Reviewers:

(1) Anonymous, Instituto Politecnico Nacional, Mexico. (2) Shweta Sharma, Dr. Ram Manohar Lohia Hospital and PGIMER, New Delhi, India. Complete Peer review History: http://sciencedomain.org/review-history/12041

Short Research Article

Received $10^{\text {th }}$ September 2015

Accepted $8^{\text {th }}$ October 2015

Published 30 $0^{\text {th }}$ October 2015

ABSTRACT

Aims: To isolate and evaluate spore-former bacteria for being used as probiotic additives in animal nutrition by their technological features.

Study Design: The study was experimental, by using calves' faeces for spore-forming identification and further evaluation of their "in vitro" probiotic-related properties.

Place and Duration of Study: Laboratory of Preventive Microbiology, Centro de Referencia para Lactobacilos (CERELA-CONICET), between June 2013 and November 2013.

Methodology: In this work, some Bacillus strains were isolated from calves' faeces and evaluated for their "in vitro" beneficial characteristics: Surface properties, biosurfactant and emulsification production, and inhibition of pathogens. The antibiotic sensibility was also assayed. 
Results: Two Bacillus strains were selected, identified by phenotypic and molecular techniques as Bacillus subtilis strains M14 and M12. Spores resulted to be more hydrophobic than vegetative cells. The M14 strain showed biosurfactant and emulsifying properties. Inhibition assays against pathogenic bacteria indicated they inhibit gram-positive microorganisms. The antibiotic susceptibility showed that the two strains were sensitive to the antibiotics assayed, except Bacillus M12 that was resistant to Kanamycin.

Conclusion: The results indicate these strains can be further studied for their inclusion in the design of a probiotic product for newborn calves.

Keywords: Calves; Bacillus-probiotics; prevention; beneficial properties.

\section{INTRODUCTION}

Probiotic additives in beef and dairy farms are alternative adjuncts to be used for animal-feed to replace antibiotics -as promoting growth factors for animals- mainly in newborn animals [1]. Most of the probiotics, defined as "live microorganisms administered to the host to produce a beneficial physiological effect" [2] applied to farm animals are formulated with Lactic Acid Bacteria (LAB) [3]. However, some Bacillus species are considered as a promising alternative for their incorporation in animal-feed [4]. Bacillus species have shown to be effective in helping to a favorable balance of the microbiota of the Gastrointestinal Tract (GIT) and a further improvement of the animal performance [5].

One of the main disadvantages of LAB probiotic products is their short shelf-life and the low resistance to the production process, in contrast to the spore former bacteria that are stable and resistant. According to the scientific reports of the European Food Safety Authority Journal (EFSA) to assess the safety of Bacillus [6], the strains must be included into the Qualified Presumption of Safety (QPS) category. Even though certain species of the Bacillus genera as $B$. subtilis group could be potentially included, the absence of some toxigenic activity must be verified.

As there is not a wide consensus on the more adequate beneficial characteristics of the sporeformer bacteria to be included in a probiotic formula, and supported by our previous experience, our research group has applied some "in vitro" assays formerly used for LAB to perform the screening and selection of those spore-former strains that could be later used for the design of a probiotic additive for calves [7-9]. Then, the objective of this work was to isolate spore-former bacteria from calves, based on the host specificity that supports the selection of probiotic microorganisms [10]. Also, to evaluate the beneficial and safety properties of bacteria considered QPS, including the antibiotic resistance profile, by employing "in vitro" assays related to the capability of the bacteria to adhere to the intestinal epithelium [11] or the production of antagonistic substances against pathogenic bacteria.

\section{MATERIALS AND METHODS}

\subsection{Isolation and Storage of the Spore- former Bacteria from Calves' Faeces}

The samples were obtained from rectum of healthy young calves 0-4 months age, collected with sterile swabs in LAPT ( $1 \%$ yeast extract, $1.5 \%$ peptone, $1 \%$ tryptone, $1 \%$ glucose, $0.1 \%$ Tween 80) broth [12] supplemented with $0.7 \%$ agar (wt/vol) as transport medium and stored at $4^{\circ} \mathrm{C}$ until processed. For spore isolation, the cultures were heated for $15 \mathrm{~min}$ at $85^{\circ} \mathrm{C}$ and maintained for $3 \mathrm{~h}$ at $37^{\circ} \mathrm{C}$ and later spread onto Nutrient Agar (NA). Plates were incubated for 24 $\mathrm{h}$ in aerobic conditions at $37^{\circ} \mathrm{C}$. The quantification of the spore-forming bacteria was not performed, because the main interest was to isolate and select those that could be screened by their beneficial properties. One to three colonies were subcultured and stored in Brain Heart Infusion (BHI, Britania, Capital Federal, Argentine) containing $20 \%$ glycerol at $-20^{\circ} \mathrm{C}$.

The study protocol was approved by the CERELA-CONICET Bioethics Committee.

\subsection{Partial Identification of Bacterial Strains}

\subsubsection{Phenotypic characterization}

The phenotypic identification was performed by standard tests for Bacillus species described in Prokaryotes [13]. Also, green malachite (Britania, Capital Federal, Argentine) staining technique was applied to check sporulation. 


\subsection{Spore Suspension}

The Bacillus spores suspensions were obtained from Nutrient Broth (NB, Britania, Capital Federal, Argentine) supplemented with 1ppm manganese $\left(\mathrm{MnSO}_{4} \cdot \mathrm{H}_{2} \mathrm{O}\right.$, Aldrich Inc, St Louis, USA) and incubated for 4 days at $32^{\circ} \mathrm{C}$ with agitation and glass beads (2mm diameter, $8 \%$ wt/vol). The spores were collected when the level of sporulation was higher than $90 \%$ (observed through direct microscopic counts in 5 fields), washed twice and re-suspended in saline solution to a $0.6-0.7 \mathrm{OD}_{600 \mathrm{~nm}}$. Later, the spore suspension was heated for $2 \mathrm{~h}$ at $80^{\circ} \mathrm{C}$ and stored at $4^{\circ} \mathrm{C}$ until use. The number of vegetative cells at the beginning of the assay and the surviving spores were determined by the agar plate technique in Nutrient Agar (NA). The sporulation index in 12 hours was calculated as the log of spores in the final spore suspension divided by the log of viable cells, multiplied by 100.

\subsection{Bacterial Surface Properties}

\subsubsection{Hydrophobicity and auto-aggregation characterization}

The hydrophobic nature of the surface of vegetative and spore cells was studied by the method of microbial adhesion to hydrocarbons as described by Ocaña et al. [7]. Autoaggregation was assessed according to the technique published by Ocaña and Nader Macías [14]. Briefly, $O D_{600 n m}$ variation of cellular and spore suspensions in saline solution was monitored for 2 hours.

\subsubsection{Screening of exopolysaccharide (EPS)}

The production of EPS in the Bacillus isolates was determined in $24 \mathrm{~h}$ cells grown in $10 \%$ sucrose medium at $37^{\circ} \mathrm{C}$. The capsular polysaccharides were evidenced by the Indian ink negative staining technique [15].

\subsubsection{Biosurfactant detection and emulsifying properties}

The biosurfactant production was screened by the oil spreading technique, as described by Youssef et al. [16]. The emulsification activity and the interphase stability were evaluated by using the modified method of Cooper and Goldenberg [17]. One $\mathrm{ml}$ Bacillus cell suspension obtained from a $24 \mathrm{~h}$ culture in NB was added to $1.5 \mathrm{ml}$ of $\mathrm{n}$-hexadecane (Merck, Darmstadt, Germany) or Kerosene. The mixture was vortexed for 2 min and the emulsion index obtained after $24 \mathrm{~h}$ by the size of the emulsion layer divided by the size of the complete suspension, multiplied by 100 .

\subsection{Screening of Antagonistic Substances Production}

\subsubsection{Hydrogen peroxide}

The production of $\mathrm{H}_{2} \mathrm{O}_{2}$ was qualitatively determined by the technique described by Juárez Tomás et al. [18]. The isolates were inoculated in the TMB-Nutrient Agar (1\%) plates and incubated for $24 \mathrm{~h}$ at $37^{\circ} \mathrm{C}$.

\subsubsection{Quantification of organic acids}

The organic acids production was quantified in the supernatants from the microorganisms grown in NB for $12 \mathrm{~h}$ with agitation at $37^{\circ} \mathrm{C}$, by using HPLC with a column for organic acids (HPX-87H $300 \times 7.8 \mathrm{~mm}$, BioRad Laboratories, Hercules, USA) at $41^{\circ} \mathrm{C} 11$ [9], the detection was carried out with an RI detector Knauer K-2301 (Knauer, Berlin, Germany).

\subsubsection{Inhibition of pathogenic bacteria}

The production of inhibitory substances was evaluated by the plate diffusion technique in the supernatant of the selected isolates [19]. Aliquots $(35 \mu \mathrm{l})$ of cell-free supernatant centrifuged for 15 min 9,300xg and sterilized by filtration from the second subculture of Bacillus grown in NB with agitation at $32^{\circ} \mathrm{C}$ were placed into holes performed in plates containing the pathogens in $0.75 \%$ agar NA. The plates were incubated $48 \mathrm{~h}$ at $37^{\circ} \mathrm{C}$. An inhibition zone of at least $6 \mathrm{~mm}$ diameter was considered positive. The microorganisms used for the detection of antagonistic substances were Salmonella Dublin $\mathrm{MP} / 07$, S. infantis $1533 / 00, S$. thyphimurium $\mathrm{MP} / 08, \quad S$. enteritidis MP/08, Yersinia enterocolitica 1845/00, Escherichia coli 3511AD, Streptococcus uberis MP/06, Klebsiella sp. $\mathrm{MP} / 05$, Staphylococcus aureus MP/08, S. epidermidis 3267, Listeria sp. MP/08, Bacillus cereus M8. Pathogens were provided by the Instituto de Microbiología of UNT (Tucumán, Argentine); INTA Rafaela (Santa Fé, Argentine); ANLIS (Buenos Aires, Argentine); and isolated in our own laboratory.

\subsection{Compatibility between Strains}

The assays to evaluate the compatibility between the selected strains were performed by 
using the plate diffusion technique [20]. Aliquots $(35 \mu \mathrm{l})$ of cell-free sterile supernatant $(12 \mathrm{~h}$ incubation centrifuged for $15 \mathrm{~min}$ at $9,300 \mathrm{xg}$ ) of the strains grown in NB with agitation at $32^{\circ} \mathrm{C}$ was placed into holes of NA supplemented$0.75 \%$ agar plates containing the Bacillus strains as indicator $\left(5 \times 10^{7} \mathrm{CFU} \mathrm{m \textrm {m } ^ { - 1 }}\right)$. The plates were incubated for $24-48 \mathrm{~h}$ and the presence of inhibitory halos was considered as positive.

\subsection{Evaluation of the Potential Virulence Factors}

\subsubsection{Antibiotic susceptibility}

Antibiotic susceptibility and Minimum Inhibitory Concentration (MIC) were determined by using the disc diffusion method according to CLSI recommendations $[20,21]$. MIC values were obtained by the serial antibiotic dilution in Mueller Hilton broth $(\mathrm{MH}$, Britania, Capital Federal, Argentine). MIC breakpoints and interpretations of the antimicrobial susceptibility were performed according to EFSA reports [22] and Hong et al. [23].

\subsubsection{Haemolytic activity and lecithinase production}

Hemolytic activity of the strains in BHI sheepblood agar (5\%) was evaluated. Lecithinase activity was determined in Cereus Selective Agar (CSA, Merck, Darmstadt, Germany) added with egg yolk emulsion (Britania, Capital Federal, Argentine). Plates were incubated for $24 \mathrm{~h}$ in aerobic conditions at $37^{\circ} \mathrm{C}$ to detect the production of hemolysis and lecithinase [24].

\subsection{Genetic Identification of the Strains}

The genetic identification of the two strains was performed by $16 \mathrm{~S}$ ribosomal RNA gene sequencing. Amplifications of DNA were carried out by colony PCR. Strains were cultured in NA; three colonies were selected and heated for 3 min at $85^{\circ} \mathrm{C}$, primers were used for PCR amplifications [25]. The amplified products were electrophoresed in $0.8 \%$ agarose gels and DNA sequencing service was performed by RuralexFagos (Capital Federal, Argentine). The identification was obtained from the Genbankdatabase by using The Basic Local Alignment Search Tool (BLAST) algorithm.

\section{RESULTS AND DISCUSSION}

Different Bacillus strains were isolated from the GIT of newborn calves, the same homologous host where the product would be applied, based on the host-specificity of the indigenous microbiota [10]. Nine spore-former bacterial strains were isolated $(n=9)$ and their partial phenotypic characterization was performed. Based on the macroscopic characteristics of the colonies on agar plates, they were stored for further identification. Although Bacillus strains are frequently isolated from soil, some authors suggest that this genus is a natural habitat of the intestine with a close relationship with animals [26]. All the isolates were spore-former microorganisms, but only two strains were identified as $B$. subtilis M12 and $B$. subtilis M14 by phenotypic and genotypic assays and were used to later study their beneficial characteristics. The other spore-forming isolates were phenotypically identified as $B$. cereus and related bacteria, and were not included in the screening, because these are species that not qualify in the QPS category [22] for their incorporation to a probiotic additive.

The use of bacterial spores for animal feed has shown resistance to the technological processes and an easier storage [27]. As the spore germination of bacilli was evidenced in the small intestine [28], the evaluation of the beneficial characteristics of the vegetative cell and spores was performed in this work. The spores of $B$. subtilis M12 $\left(5 \times 10^{7}\right.$ spores $\left.\mathrm{ml}^{-1}\right)$ and M14 $\left(1 \times 10^{9}\right.$ spores $\mathrm{ml}^{-1}$ ) were collected after the sporulation procedure. The index of sporulation for $B$. subtilis $\mathrm{M} 12$ and $\mathrm{M} 14$ was $79 \%$ and $92 \%$ respectively, showing that the spore-forming capability is specific or different for each strain.

The results indicate that the hydrophobicity of the spores was higher than those of vegetative cells, and similar findings were published by others authors [29]. Neither the vegetative cells nor the spores showed auto-aggregation.

Emulsifying properties and biosurfactant production were detected in the strains in contact with hexadecane and kerosene (Table 1; Fig. 1), showing stable emulsions and a weak production of surfactant. The most common site for the isolation of microorganisms that produce biosurfactant is the hydrocarbon-contaminated sites; nevertheless some authors suggest that the application of a screening technique is the basis for the detection of those that produce biosurfactants [30].

The biosurfactant production assayed in the stationary phase of growth indicated that only 
B. subtilis M14 produced a weak biosurfactant by the oil spreading technique (Table 2). The use of biosurfactants is related not only with bioremediation and pharmaceutical products, but also applied in the medical field as protection against pathogens [31]. Some authors [32] relate the emulsifying characteristics with the surface hydrophobicity and production of biosurfactants in Bacillus subtilis. This emulsificant technique applied to detect biosurfactants could be suggested as an "in vitro" method to evaluate the beneficial properties in the Bacillus genus. Also, antimicrobial properties should be evaluated when looking for surfactant activities, because the surfactancts have shown the ability to destabilize the biological membranes of pathogens by their pore forming capacity [33].

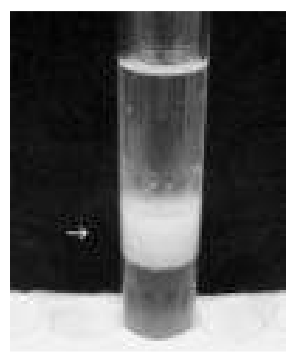

Fig. 1. Emulsions produced by $B$. subtilis M14 supernatant when added to hexadecane

Referred to the EPS production, the two strains showed to produce EPS in solid agar medium and a weak formation of capsules in the case of $B$. subtilis M14 by the Indian ink negative stain. B. subtilis M14 produced a hard floating biofilm when incubated in static and aerobic conditions.

Different inhibitory substances produced by Bacillus were reported, most of them against gram-positive bacteria. The two $B$. subtilis strains inhibited the growth of all the grampositive pathogens assayed (Fig. 2, Table 2). Further studies are being performed to determine the chemical nature of the inhibitory substances, because a bacteriocin-like substance, as subtilin or a natural antibiotic could be involved [4]. On the other hand, they did not inhibit any of the gram-negative microorganisms assayed. Lactic acid production was not detected by HPLC. The two strains were compatible, because they did not inhibit each other, and were not able to produce $\mathrm{H}_{2} \mathrm{O}_{2}$ in the medium assayed, then can be included in the design of a probiotic product.

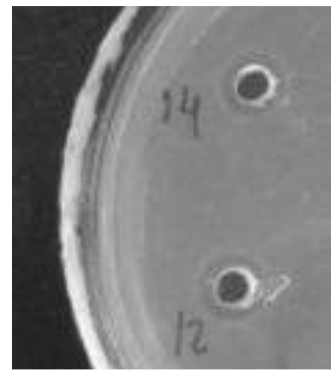

Fig. 2. Production of antagonistic substances by Bacillus subtilis M12 (12) and M 14 (14) by using Listeria sp as indicator

Antibiotic susceptibility indicates that the Bacillus strains were sensitive to all the antibiotics assayed, except $B$. subtilis M12 that showed resistance to Kanamycin, according to EFSA breakpoints [22] (Table 3a, b). Other authors confirmed the resistance of $B$. subtilis 2335(105) to Kanamycin in a commercial probiotic strain, by a gene responsible of the cross resistance to Amikacin and Tobramycin [34].

Table 1. Surface properties, emulsification, biofilm and exopolysaccharides (EPS) production in spore-former bacteria

\begin{tabular}{|c|c|c|c|c|c|c|c|c|}
\hline & $\begin{array}{l}\text { Hydropl } \\
\text { index ( }\end{array}$ & $\begin{array}{l}\text { hobic } \\
\%)^{a^{*}}\end{array}$ & $\begin{array}{r}\text { Autoaggr } \\
\text { patte }\end{array}$ & $\underset{n^{\dagger}}{\text { gation }}$ & $\begin{array}{l}\text { EPS } \\
\text { production }^{\ddagger}\end{array}$ & $\begin{array}{l}\text { Biofilm } \\
\text { production }^{\S}\end{array}$ & $\begin{array}{l}\text { Emuls } \\
\text { prope }\end{array}$ & $\begin{array}{l}\text { ifying } \\
\text { rties }\end{array}$ \\
\hline & $\begin{array}{l}\text { Vegetative } \\
\text { cell }\end{array}$ & Spore & $\begin{array}{l}\text { Vegetative } \\
\text { cell }\end{array}$ & Spore & & & $\begin{array}{l}\text { Hexa- } \\
\text { decane }\end{array}$ & $\begin{array}{l}\text { Kero- } \\
\text { sene }\end{array}$ \\
\hline $\begin{array}{l}\text { Bacillus subtilis } \\
\text { M12 }\end{array}$ & $10.5 \pm 1$ & $35.0 \pm 8$ & $(-)$ & $(-)$ & $(+)$ & $(-)$ & $27.4 \pm 8$ & $29.6 \pm 5$ \\
\hline $\begin{array}{l}\text { Bacillus subtilis } \\
\text { M14 }\end{array}$ & $6.2 \pm 3$ & $38.5 \pm 15$ & $(-)$ & $(-)$ & $(+)$ & $(+)$ & $9.8 \pm 3$ & $25.7 \pm 1$ \\
\hline
\end{tabular}


Table 2. Inhibitory substances produced by spore-former bacteria

\begin{tabular}{|c|c|c|c|c|}
\hline & Inhibitory activity & $\begin{array}{l}\text { Lactic } \\
\text { acid }^{\dagger}\end{array}$ & $\begin{array}{l}\text { Hydrogen } \\
\text { peroxide }\end{array}$ & Biosurfactant $^{\S}$ \\
\hline $\begin{array}{l}\text { Bacillus subtilis } \\
\text { M12 }\end{array}$ & $\begin{array}{l}\text { Staphylococcus aureus MP/08 S. } \\
\text { epidermidis } 3267 \text { Streptococcus uberis } \\
\text { MP/06 Listeria sp. MP/08 Bacillus cereus } \\
\text { M8 }\end{array}$ & $(-)$ & $(-)$ & $(-)$ \\
\hline $\begin{array}{l}\text { Bacillus subtilis } \\
\text { M14 }\end{array}$ & $\begin{array}{l}\text { Staphylococcus aureus MP/08 S. } \\
\text { epidermidis } 3267 \\
\text { Streptococcus uberis MP/06 Listeria sp. } \\
\text { MP/08 Bacillus cereus M8 }\end{array}$ & $(-)$ & $(-)$ & $(+)$ \\
\hline \multicolumn{5}{|c|}{${ }^{*}$ Analyzed by the plate diffusion method. } \\
\hline
\end{tabular}

Table 3a. Antibiotic susceptibility of the spore-former strains

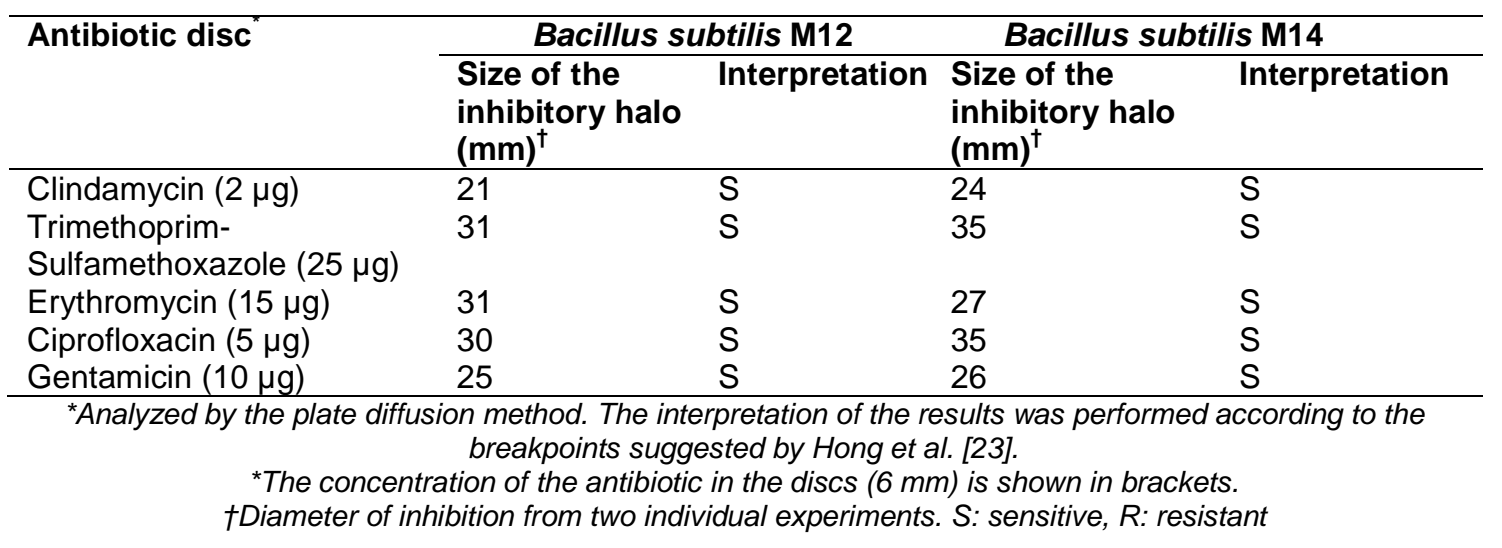

Table 3b. Antibiotic susceptibility of the spore-former strains. Determination of the minimum inhibitory concentration (MIC)

\begin{tabular}{llll}
\hline Antibiotic & \multicolumn{2}{c}{ MIC $(\boldsymbol{\mu g} / \mathbf{m l})$} & Breakpoints $^{*}$ \\
\cline { 2 - 3 } & Bacillus subtilis M12 & Bacillus subtilis M14 & \\
\hline Chloramphenicol & 16 & 16 & $\geq 8$ \\
Tetracycline & 4 & 4 & $\geq 8$ \\
Oxytetracycline & 4 & 8 & ND \\
Kanamycin & 64 & $<0.25$ & $\geq 8$ \\
Erythromycin & 2 & 0.5 & $\geq 4$ \\
\hline \multicolumn{3}{c}{ ND: not determined } \\
\end{tabular}

The safety assays (lecithinase and hemolysis tests) indicate that the two strains do not have cytotoxic phospholipases or produce a weak alpha-hemolysis in sheep blood, and did not showed lecithinase activity. Animal studies have shown that $B$. cereus IP 5832, a hemolytic strain, produced acute toxicity by the intra-peritoneal administration in mice, in contrast with $B$. subtilis 3 and $B$. licheniformis 31 with no hemolytic properties [23].

\section{CONCLUSION}

The results obtained in this paper show that some techniques applied to determine the beneficial properties of Lactic Acid bacteria could be used for the screening of this type of characteristics in spore-forming bacteria. The two Bacillus strains selected are being evaluated to define their inclusion in a product for calves. The results obtained support their use as 
probiotic according to the EFSA recommendations, and they could be combined with the LAB previously selected for their beneficial properties [9], to restore the intestinal microbioma of calves as multi-strains-hostspecific probiotic.

\section{ACKNOWLEDGEMENTS}

This work was supported by grants from CONICET: PIP 744, and ANPCYT: PICT 1187.

\section{COMPETING INTERESTS}

Authors have declared that no competing interests exist.

\section{REFERENCES}

1. Gaggìa F, Mattarelli $\mathrm{P}$, Biavati $\mathrm{B}$. Probiotics and prebiotics in animal feeding for safe food production. Int $\mathrm{J}$ Food Microbiol. 2010;1411:15-28.

2. Reid G, Sanders ME, Gaskins HR, Gibson GR, Mercenier A, Rastall R, Roberfroid M, Rowland I, Cherbut C, Klaenhammer TR. New scientific paradigms for probiotics and prebiotics. J Clin Gastroenterol. 2003; 37:105-118.

3. Chaucheyras-Durand $F$, Durand $H$. Probiotics in animal nutrition and health. Benef Microbes. 2010;1(1):3-9.

4. Cutting SM. Bacillus probiotics. Food Microbiol. 2011;28:214-20.

5. Kritas SK, Marubashi T, Filioussis G, Petridou E, Christodoulopoulos G, Burriel AR, Tzivara A, Theodoridis A, Pískoriková $M$. Reproductive performance of sows was improved by administration of a sporing bacillary probiotic (Bacillus subtilis C3102). J Anim Sci. 2015;93:405-13.

6. EFSA. Scientific opinion of the panel on biological hazards. The maintenance of the list of QPS microorganisms intentionally added to food or feed. EFSA J. 2008;923:1-48.

7. Ocaña VS, Bru E, de Ruiz Holgado AP, Nader Macías ME. Surface characteristics of lactobacilli isolated from human vagina. J Gen Appl Microbiol. 1999;45:203-212.

8. Nader Macías ME, Otero MC, Espeche MC, Maldonado NC. Advances in the design of probiotic products for the prevention of major diseases in dairy cattle. J Ind Microbiol Biotechnol. 2008; 35:1387-95.
9. Maldonado NC, de Ruiz Silva C, Otero MC, Sesma F, Nader-Macías ME. Lactic acid bacteria isolated from young calves characterization and potential as probiotics. Res Vet Sci. 2012;92(2):342-9.

10. Kleerebezem M, Vaughan EE. Probiotic and gut lactobacilli and bifidobacteria: Molecular approaches to study diversity and activity. Annu Rev Microbiol. 2009;63: 269-290.

11. Pan WH, Li PL, Liu Z. The correlation between surface hydrophobicity and adherence of Bifidobacterium strains from centenarians' faeces. Anaerobe. 2006;12: 148-52.

12. Raibaud $P$, Galpin JV, Ducluzeau R, Mocquot F, Oliver $G$. The genus Lactobacillus in the gastrointestinal tract of rats. II Characteristic of heterofermentative isolates strains of rats "Holo" and "Gnotobiotic". Ann Microbiologie. 1963; 124:2223-35.

13. Farrar E, Reboli AC. The genus bacillusmedical. In the prokaryotes 3rd ed. Dworkin M, Falkow S, Rosenberg E, Schleifer KH, Stackebrandt E. New York: Springer Science and Business Media Inc. 2007;609-630.

14. Ocaña VS, Nader Macías ME. Vaginal lactobacilli: Self and co-aggregating ability. Brit J Biomed Sci. 2002;59:183-190.

15. Mozzi F, Torino MI, De Valdez GF. Identification of exopolysaccharideproducing lactic acid bacteria. A method for the isolation of polysaccharides in milk cultures. In Spencer JFT, Ragout de Spencer A, editors: Food microbiology protocols methods in biotechnology New Jersey: Humana Press Inc. 2004;14.

16. Youssef $\mathrm{NH}$, Duncan KE, Nagle DP, Savage KN, Knapp RM, Mc Inerney MJ. Comparison of methods to detect biosurfactant production by diverse microorganisms. J Microbiol Meth. 2004; 56:339-47.

17. Cooper DG, Goldenberg BG. Surfaceactive agents from two bacillus Species. Appl Environ Microb. 1987;53:224-229.

18. Juárez Tomás MS, Otero MC, Ocaña VS, Nader-Macías ME. Production of antimicrobial substances in lactic acid bacteria I. Determination of hydrogen peroxide. In: Spencer JFT, Ragout de Spencer A, editors: Public health microbiology: Methods and protocols. New Jersey: Humana Press Inc. 2004;268. 
19. Jack RW, Tagg JR, Ray B. Bacteriocins of gram positive bacteria. Microbial Reviews. 1995;59:171-200.

20. CLSla, Approved standard M7-A7. Methods for dilution antimicrobial susceptibility tests for bacteria that grow aerobically. Wayne, PA: Clinical and Laboratory Standards Institute; 2006.

21. CLSIb, Approved standard M2-A9. Performance standards for antimicrobial disk susceptibility tests. Wayne, PA: Clinical and Laboratory Standards Institute; 2006.

22. EFSA. Opinion of the scientific committee on a request from EFSA related to a generic approach to the safety assessment by EFSA of microorganisms used in food/feed and the production of food/feed additives. EFSA J. 2005;226: 1-12.

23. Hong HA, Huang JM, Khaneja R, Hiep LV, Urdaci MC, Cutting SM. The safety of Bacillus subtilis and Bacillus indicus as food probiotics. J Appl Microbiol. 2008; 105:510-20.

24. Sorokulova IB, Pinchuk IV, Denayrolles M, Osipova IG, Huang JM, Cutting SM, Urdaci MC. The safety of two Bacillus probiotic strains for human use. Digest Dis Sci. 2008;53;954-63.

25. Hébert EM, Raya RR, De Giori GS. Nutritional requirements and nitrogendependent regulation of proteinase activity of Lactobacillus helveticus CRL 1062. Appl Environ Microbiol. 2000;66;5316-21.

26. Hong HA, To E, Fakhry S, Baccigalupi L, Ricca E, Cutting SM. Defining the natural habitat of Bacillus spore-formers. Res Microbiol. 2009;160;375-79.

27. Bader J, Albin A, Stahl U. Spore-forming bacteria and their utilisation as probiotics Benef Microbes. 2012;3(1):67-75.

28. Leser TD, Knarreborg A, Worm J. Germination and outgrowth of Bacillus subtilis and Bacillus licheniformis spores in the gastrointestinal tract of pigs. $\mathrm{J}$ Appl Microbiol. 2008;104; 1025-33.

29. Rönner U, Husmark U, Henriksson A. Adhesion of bacillus spores in relation to hydrophobicity. J Appl Bacteriol 1990;69: 550-56.

30. Walter V, Syldatk C, Hausmann R. screening concepts for the isolation of bio surfactant producing microorganisms. Adv Exp Med Biol. 2010;672:1-13.

31. Rodrigues L, Banat IM, Teixeira J, Oliveira R. Bio surfactants: Potential applications in medicine. J Antimicrob Chemother. 2006; 57:609-18.

32. Ahimou F, Jacques $P$, Deleu M. Surfactin and iturin A effects on Bacillus subtilis surface hydrophobicity. Enzyme Microb Technol. 2000;27(10):749-54.

33. Inès $M$, Dhouha $G$. Lipopeptide surfactants: Production, recovery and pore forming capacity. Peptides. 2015;71: 100-12.

34. Smirnov VV, Rudenko AV, Samgorodskaia NV, Sorokulova IB, Reznik SR, Sergechuk TM. Susceptibility to antimicrobial drugs of strains of bacilli used as a basis for various probiotics. Antibiot Khimioter. 1994;39:23-8.

(c) 2016 Maldonado et al.; This is an Open Access article distributed under the terms of the Creative Commons Attribution License (http://creativecommons.org/licenses/by/4.0), which permits unrestricted use, distribution, and reproduction in any medium, provided the original work is properly cited.

Peer-review history:

The peer review history for this paper can be accessed here: http://sciencedomain.org/review-history/12041 